\title{
QUIETING THE VIRTUAL PRISON RIOT: WHY THE INTERNET'S SPIRIT OF "SHARING" MUST BE BROKEN
}

\begin{abstract}
Albert Z. Kovacs
[I]t's amazing what you can do when you don't have to look at yourself in the mirror anymore.

HOLLOW MAN ${ }^{1}$

To demand equality of rights ... as the socialists of the subject caste do, is never an emanation of justice but of greed. - If one holds up bleeding chunks of meat to an animal and takes them away again until it finally roars: do you think this roaring has anything to do with justice?
\end{abstract}

Friedrich Nietzsche ${ }^{2}$

Thou shalt not steal.

Exodus 20:15

\section{INTRODUCTION}

The Internet has changed much about everyday life. The way people shop. The way they communicate. The way they conduct business. The way they buy airline tickets and get driving directions. The Internet promises freedom from many of the delays and limitations of the physical world. But in doing so, could the Internet also distance people from the rules and moral conceptions that bind them in the "real world"?

Copyright (C) 2001 by Albert Z. Kovacs.

1. (Columbia Pictures 2000).

2. Friedrich Nietzsche, Human, All Too Human 165 (R.J. Hollingdale trans., Cambridge Univ. Press 1986) (1886) (second emphasis added).

3. (King James). 
Because in cyberspace people can exist independent of their names, identities, faces, and personalities, they often transcend the real world's moral and legal boundaries. Although the Internet allows them to transcend or violate these boundaries more easily, it generally has not changed moral and ethical concepts-notions of what it means to "do wrong." However, these notions are under attack. The ease with which content on the Internet can be (often erroneously) categorized as mere "information" threatens to erode legal conceptions of intellectual property protection and our ethical definition of theft.

Using Michel Foucault's historical analysis of punishment and the development of disciplinary surveillance, I argue that the "spirit of sharing" that has developed on the Internet is effectively a revolt against the "prison" erected by copyright law. To assert their proprietary rights effectively, successfully, and with both legal and moral authority, the recording industry (and other content-based industries) must break that "spirit of sharing" by making a visible display of power in cyberspace. By publicly "torturing" Napster ${ }^{4}$ and similar

4. Napster is a web-based service that allows its users to exchange digital music files over the Internet. See A\&M Records, Inc. v. Napster, Inc., 239 F.3d 1004, 1011 (9th Cir. 2001):

Napster facilitates the transmission of MP3 files between and among its users. Through a process commonly called "peer-to-peer" file sharing, Napster allows its users to: (1) make MP3 music files stored on individual computer hard drives available for copying by other Napster users; (2) search for MP3 music files stored on other users' computers; and (3) transfer exact copies of the contents of other users' MP3 files from one computer to another via the Internet. These functions are made possible by Napster's MusicShare software, available free of charge from Napster's Internet site, and Napster's network servers and server-side software. Napster provides technical support for the indexing and searching of MP3 files, as well as for its other functions, including a "chat room," where users can meet to discuss music, and a directory where participating artists can provide information about their music.

The complaint against Napster alleged that the service contributorily and vicariously infringed the plaintiff music companies' copyrights in their music recordings, many of which were transferred between and among Napster users. Id. On July 26, 2000, the district court granted the plaintiffs' motion for a preliminary injunction that would prevent Napster "'from engaging in, or facilitating others in copying, downloading, uploading, transmitting, or distributing plaintiffs' copyrighted musical compositions and sound recordings, protected by either federal or state law, without express permission of the rights owner." Id. (quoting A\&M Records, Inc. v. Napster, Inc., 114 F. Supp. 2d 896, 927 (N.D. Cal. 2000)). The Court of Appeals for the Ninth Circuit affirmed in part and reversed in part, but generally recognized "that a preliminary injunction against Napster's participation in copyright infringement is not only warranted but required." Id. at 1027. After the Ninth Circuit's decision, Napster still was enjoined from allowing its users to transfer copyrighted materials if Napster had knowledge that those materials were legally protected. $I d$. Both the Recording Industry Association of America and Napster websites contain the legal documents associated with the Napster lawsuit. See riaa/news: Current Issues, Recording Industry Association of America, at http://www.riaa.org/napster_legal.cfm (last visited Sept. 5, 2001) (on file with the Duke Law Journal); Legal Documents, Napster, at http://www. 
file-exchange services, ${ }^{5}$ the content industries ${ }^{6}$ are taking a first step toward quelling the virtual rebellion against copyright. ${ }^{7}$

\section{THE PROBLEMATIC MORALITY OF THE INTERNET}

Through its decentralized architecture, which promises free communication, the Internet has modified concepts of property and information, seducing an entire generation into associating copyright infringement and theft of intellectual property with "discourse" and "sharing."

\section{A. The Original Structure of the Internet}

The Internet was designed as a communications system that could survive a nuclear war; communication on the network depends not on any single path of information flow or central server, but on a "distributed" architecture that can circumvent system failures or blockages. ${ }^{8}$ An oft-quoted comment by Electronic Frontier Foundation $^{9}$ cofounder John Gilmore sums up the original, and to some ex-

napster.com/pressroom/legal.html (last visited Sept. 5, 2001) (on file with the Duke Law Journal); see also infra note 94 and accompanying text (describing more recent developments in the lawsuit and Napster's reaction to the revised preliminary injunction).

5. For example, services like Kazaa, Grokster, and MusicCity allow users to scour other Internet users' hard drives for copyrighted songs, music, movies, photographs, and software free of charge. Jefferson Graham, Napster Proteges Under Fire from Entertainment Industry, USA TODAY, Oct. 4, 2001, at 3D.

6. While the Napster lawsuit is known primarily for its implications for the music recording industry, the concept of "file sharing" poses a threat beyond the music industry. By the term "content industries," I intend to refer not only to the music industry, but also to other media companies, such as motion picture and television production companies, as well as to those that produce and distribute computer software.

7. The reader should be aware that this Note takes as a starting presumption that our existing system of copyright laws is valid and justifiable. This is not to be construed as an endorsement of all forms of intellectual property protection, but merely as a foundational assumption for my argument. I leave the criticism and deconstruction of copyright to cyber-libertarians and open-source advocates.

8. James Boyle, Foucault in Cyberspace: Surveillance, Sovereignty, and Hardwired Censors, 66 U. CIN. L. REV. 177, 179 (1997).

9. See id. at 178. The Electronic Frontier Foundation describes itself as "a donorsupported membership organization working to protect our fundamental rights regardless of technology; to educate the press, policymakers and the general public about civil liberties issues related to technology; and to act as a defender of those liberties." Electronic Frontier Foundation, About EFF: General Information About the Electronic Frontier Foundation, at http://www. eff.org/abouteff.html (last visited Oct. 31, 2001) (on file with the Duke Law Journal). 
tent current, popular conception of the Internet: "The Net interprets censorship as damage and routes around it." 10

The Internet's capacity to circumvent obstacles to data flow has created a new means of communication that seems to eliminate the possibility of censorship or centralized authoritarian monitoring, control, or supervision. This unsupervised realm promises to be a paradise island for those who yearn for a truly free and seemingly infinite exchange of ideas, restricted neither by physical location nor by social or political convention or stigmatization. "In the utopian vision, a worldwide digital network transcends national borders and promotes open dialogue, cooperation, and self-regulation. It is a vision of free and robust scientific, artistic, educational, and political interaction. It is a model of 'any-to-any,' a two-way street where all recipients are also producers of information."

This "utopian vision" of discourse on the Internet seems to realize what long has been a political ideal: ${ }^{12}$ the free exchange of ideas from one person to another, without interference from the state. In the "real world" (at least in the "real" United States), the Constitution limits with words the power of the government to control the intellectual interaction of the citizenry. ${ }^{13}$ In the virtual world, freedom from state supervision and intervention ${ }^{14}$ promises that ideal intellectual exchange can be completely realized. The Internet can transform "politics by making true dialogue and free debate available to everyone," 15 allowing its users the freedom to disseminate their thoughts

10. Boyle, supra note 8, at 178. Although the exact phrasing of Gilmore's comment is uncertain, his meaning is not. See id. at $178 \mathrm{n} .3$ (noting the uncertainty regarding the exact quotation and that even Gilmore himself cannot remember exactly where he originally made the statement). (1996)

11. Margaret Jane Radin, Property Evolving in Cyberspace, 15 J.L. \& COM. 509, 513

12. See John Stuart Mill, On Liberty 19-67 (Currin V. Shields ed., Macmillan Publ'g Co. 1956) (1859) (presenting four arguments to establish "the necessity to the mental well-being of mankind [on which all their other well-being depends] of freedom of opinion, and freedom of the expression of opinion").

13. See U.S. CONST. amend. I ("Congress shall make no law ... abridging the freedom of speech, or of the press ....").

14. See, e.g., Expert Report of Professor Lawrence Lessig Pursuant to Federal Rule of Civil Procedure 26(a)(2)(B), at II 27, A\&M Records, Inc. v. Napster, Inc., 114 F. Supp. 2d. 896 (N.D. Cal. 2000) (No. 99-5183) [hereinafter Lessig] ("States that previously controlled the access by their citizens to certain political or cultural speech found it hard to effect that control after the deployment of the Internet... The consequence was an expansion of free speech internationally."), available at http://dl.napster.com/lessig.pdf (June 2000) (on file with the Duke Law Journal).

15. Radin, supra note 11 , at 513. 
and to access the thoughts of others, with peer criticism and commentary the only possible forms of censorship. The anonymity and metaphysicality ${ }^{16}$ of the Internet promises to free its users from the burdens of both their location in the physical world and the socioeconomic strata that define it. By shedding names, bodies, and faces-and thus to a large degree their real-world identities-people can interact (and be judged) in a realm of ideas as ideas themselves.

\section{B. Digital Anonymity and Moral Independence}

The anonymity and freedom from physical restriction that the Internet provides generally has not changed our value systems or ethical mores. However, in the area of copyright and intellectual property, they encourage a systematic mutation of our concepts of property and "sharing."

The structure and design of the Internet promise the development of a freer and more expansive exchange of knowledge and an explosive increase in political and cross-cultural discourse. In that sense, the anonymity and metaphysicality of the system allow people to escape the restrictions of the real world that would inhibit communication. But the very features of the Internet that hold its greatest promise also permit users of the system to shed some of the beneficially restrictive norms, laws, and moral structures that govern behavior in the real world.

When one enters cyberspace, one can abandon almost all things "real" about one's self; name, face, gender, age, nationality, and religion all can be erased, hidden, or changed. The inhibitions and restrictions that accompany one's place and identity in the real world can vanish in the virtual one. In a realm of imagination and ideas, the very notion of reality falls away. What would be impossible or impracticable in the real world-for example, a face-to-face, real-time conversation among students located at different corners of the globe-becomes possible and even commonplace on the Internet. Similarly, activities and behavior that are rendered impossible or impracticable by law, moral edict, or social pressure become possible once the contextual reality that gives those commands their authorita-

16. The term "metaphysicality," as used in this Note, refers to a state of being beyond the physical plane. In the context of the current discussion of the Internet, it refers to that cyberspatial quality that allows people to exist in a realm beyond the physical or "real" world, a realm where people exist merely as minds, characters, and ideas, absent the restrictions and limitations of being located in physical space. 
tive force fades away. In the real world, one's conduct is governed largely by one's location in space, which creates physical limitations on behavior and helps to determine applicable law, and cultural context, which defines social behavioral expectations and norms. The virtual world for many seems different from the real world in a moral sense, and that difference has varying degrees of impact.

In a statement regarding the protection of intellectual property on the Internet, United States Attorney General Janet Reno recounted the following anecdote:

A man once told me, a man well-versed [in computer crimes]: "You know, my 13-year-old daughter knows that she can't open other people's physical mail and read it. She doesn't go into her sister's bedroom when the door is closed. She doesn't rumble through her drawers without permission. But she doesn't know how to act on line. She doesn't know what to do with other people's email." ${ }^{17}$

This is one of the more harmless examples of the moral confusion that results from the physical "depersonalization" of the Internet. It shows that the simple personal courtesies extended to others, and the privacy boundaries almost instinctively respected can be confused, neglected, or simply ignored on the Internet. It is easier-and thus more tempting - to snoop in cyberspace because it is easier to avoid detection.

The moral dilemma that results from the libertarian structure of much of the Internet stems from what can be seen as the dual citizenship of the "netizen." When one inhabits cyberspace, one is still physically present in the real world, but one also exists on another metaphysical plane. The Internet provides a vehicle by which people can escape the restrictions of the real world without having to sacrifice the security and benefits it holds for them. In this sense, one can view the Internet as a fantasy world or escape from reality, where one can harmlessly transcend moral restrictions without paying any "real" penalty. Professor Lawrence Lessig describes an example of such an escapist, a college student named Jake who published stories on a $\mathrm{USENET}^{18}$ group called alt.sex.stories: "Jake was a character in his

17. Janet Reno, Statement at the Symposium of the Americas: Protecting Intellectual Property in the Digital Age (Sept. 12, 2000), available at http://www.cybercrime.gov/ ipsymposium.htm (last visited Sept. 5, 2001) (on file with the Duke Law Journal).

18. USENET is an electronic bulletin-board system accessible via the Internet and other online services, which contains more than 14,000 forums, called "newsgroups," each of which relates to a particular area of interest. USENET_Webopedia Definition and Links, Webopedia, 
own stories, yet who he was in his stories was quite different from who he was in 'real' life. . . Jake wrote stories about violence-about sex as well, but mainly about violence. They seethed with hatred, especially of women."19

In Jake's stories, he could display his own brand of despicable "bravery" and become a hero to those who admired his work. These were expressive possibilities and outlets that Jake never would have had save for the Internet. He may have been able to publish his work in the real world, but his audience would have been much smaller and the rewards less significant. ${ }^{20}$ In the real world, Jake was unable, or simply unwilling, to express the depravity that lurked within his imagination. But on the Internet, his depravity found an outlet and more-an eager, (blood)thirsty audience more than willing to receive, applaud, and demand more of the same. In the real world, Jake was someone bound by morals, norms, and social convention. "On the Net he was someone else."21

The previous examples represent two possible manifestations of the Internet's unrestricted nature: first, a simple transgression of common courtesy, and second, a slicing expression of socially unwelcome fantasy. While each of these may be morally troubling to some, they pose little threat of harm to the real world. ${ }^{22}$ What is most trou-

at $\mathrm{http}: / /$ webopedia.internet.com/TERM/U/USENET.html (last visited June 7, 2001) (on file with the Duke Law Journal).

19. LAWrence Lessig, Code AND Other Laws of Cyberspace 14-15 (1999). Criminal charges brought against Jake were later dismissed on First Amendment grounds. See United States v. Baker, 890 F. Supp. 1375, 1390 (E.D. Mich. 1995).

20. "Jake had discovered a way to mainline his depravity into the veins of a public for whom this stuff was otherwise quite difficult to find. (Even Hustler wouldn't publish the likes of this.)" LESSIG, supra note 19, at 16.

21. Id. at 17.

22. Some may balk at my classification of the first example-reading another person's e-mail—as "relatively harmless." However, that activity is, in my opinion, the sort of impolite conduct that can be corrected without resort to complicated moral logic. It does not take a difficult mental leap to analogize e-mail to its physical predecessor, and thus the young person who capriciously violates another's postal privacy can be reminded relatively easily that she is engaging in the digital equivalent of envelope-steaming. I also classify Jake's stories as "relatively harmless" because they generally represent fantasy. They may be horrible, wicked, and vicious, but they are fantasies - creations of the imagination. In that sense, they may actually prevent the real-world manifestation of the horrors they contain. But see Amy Lynne Bomse, Note, The Dependence of Cyberspace, 50 DuKE L.J. 1717, 1748-49 (2001) (concluding that "[t]he Internet does not exist apart from the world in which it was created and in which its users ... reside" and suggesting that "[w]hile one can sympathize with and even share in a fantasy of escape, via cyberspace travel, from the tediously fractious and difficult human condition, this fantasy is not a useful premise on which to base public policy"). One might analogize this type of expression to the works of the Marquis de Sade, which can be viewed as having been created at least in part as 
bling is when the freedom and libertarianism of the Internet threatens the moral and legal constructs of the real world, permitting people to cultivate their repressed desires and instincts by facilitating acts in cyberspace that would be illegal and far less practicable in the real world.

Perhaps the clearest and most disturbing example of this phenomenon is that of a pedophile soliciting minors online. In many instances, adults have solicited children (or law enforcement officers posing as children) for explicit sexual conversations online, and have attempted to make real-world contact with them, either by arranging meetings for actual sexual intercourse or by exchanging photographs or other media involving sexual activities." "Surreptitious and anonymous predators can disguise their identities and prey on young people or others who [sic] they simply trust when they meet them online." ${ }^{24}$ As Professor Lessig points out, the anonymity of the Internet, coupled with its severance from the physical world, allows this type of criminal to be more effective than he could be in the real world: "Without this technology, it would be relatively hard for the same adults to engage in such conversations with kids (thirty-five year old men roaming playgrounds are usually easily noticed); with the technology, this criminal activity is increased." ${ }^{25}$ The anonymity and metaphysicality of the Internet again produce an escape from some of the limitations of real-world morality and its normative structures. But even this example of the Internet's facilitation of moral failure does not represent a change in society's moral and ethical systems.

rebellious drama meant to shock the conscience of the general public, allowing the reader to escape, momentarily and relatively harmlessly, the often mundane existence of the real world. For an example of DeSade's work, see generally MARQUIS DE SADE, THE 120 DAYS OF SODOM AND OTHER WRITINGS (Richard Seaver ed., 1987) (1785). Surely a coward such as Jake, who would not even dare in the real world to express publicly the violent hatred festering in his mind, would not (with rare exception) dare an actual enactment of such sexual violence. For a more generalized explication of sexuality, excess, literature and their roles in the religious transcendence of everyday existence, see generally GEORGES BATAILLE, EROTISM: DEATH AND SENSUALITY (Mary Dalwood trans., City Lights Books 1986) (1957).

23. For two examples, see United States v. Bailey, 228 F.3d 637, 639-40 (6th Cir. 2000), cert. denied, 121 S. Ct. 1737 (2001) (describing an online predator who had used the alias "Stealth725" to contact minor girls for sexually explicit conversation, and who had attempted to arrange meetings with the girls he had met online); United States v. Crow, 164 F.3d 229, 231-32 (5th Cir. 1999), cert. denied, 526 U.S. 1160 (1999) (describing a man who, using the online alias "VideoDom," repeatedly contacted an undercover agent [posing as a thirteen-year-old girl], offering her money to send him videos of herself engaged in explicit sex acts).

24. Reno, supra note 17.

25. Lessig, supra note 14, II 27. 
Although the Internet might facilitate the occasional invasion of personal privacy (the child's reading someone else's e-mail), encourage the production of deviant fantasies in the mind of a repressed libertine (Jake's telling violent sex stories), or perhaps make it easier for certain particularly vile criminals to approach their victims (the sex offender's stalking children), can the Internet be blamed for any actual degradation of real-world moral norms? The architecture of the Internet might facilitate these transgressions, but can that architecture really carry the blame for the moral attitudes of its users? In the above examples, the answer is no.

The young girl reading her sister's e-mail is probably doing nothing more than she would do had she a similar opportunity in the real world-namely invading the privacy of another when the chance of detection is slight. The Internet just makes it easier for her to avoid the consequences of her moral choice. The sexually and socially underdeveloped author who shares his demented fantasies with likeminded individuals is doing no more than digitizing the ideas that would occupy his mind regardless; the Internet merely provides the vent through which that repressed energy can dissipate. And many child molesters will seek out victims with or without a computer. The Internet might make it slightly easier for the perpetrator to escape detection, but the decision to violate society's sexual taboos is made long before he enters any Internet chat room.

It would then seem that the Internet, while facilitating moral transgressions, has done nothing to affect the moral values and ethical systems people transgress. To put it simply, although the Internet may in some instances make it easier to "be bad," it has not changed what it means to "be bad." If the architecture of the Internet is not responsible for the moral values that lead to virtual transgressions, then it is unlikely that changing that architecture will have any real reformatory effect. But there is one area in which the architecture and structure of the Internet appear to be degrading the legal, moral, and normative constructs of the real world-namely the theft of intellectual property.

The supposedly uncontrolled (and at least formerly uncontrollable) nature of the Internet produces a free flow of information, an exchange of ideas with perhaps only infinitesimal recognition of the restrictions and limitations of the real world. This unrestricted flow of information results in a mutation and misunderstanding of property rights and has seduced a generation into equating stealing with "sharing." The architecture of the Internet appears to be largely, if 
not entirely, responsible for the moral values that have spawned the virtual spirit of sharing. Thus, a change in that architecture not only might control actual transgressions, but also might reform the confused ethical constructs that are responsible for them.

\section{Intangibility, the Myth of Free Information, and the Free-For-All Ethic of Cyberspace}

The Internet's architecture allows users to exist in a digital plane where information and other data travel with few restrictions. This architecture tempts users to identify all content as "information" once it is separated from a physical storage or transfer medium. It is this alluring misconception that distorts legal concepts of property and ethical prohibitions against theft.

Intellectual property law cannot be patched, retrofitted, or expanded to contain the gasses of digitized expression any more than real estate law might be revised to cover the allocation of broadcasting spectrum. ... Digital technology is detaching information from the physical plane, where property law of all sorts has always found definition. ${ }^{26}$

In his article Selling Wine Without Bottles, John Perry Barlow describes his vision for the future of copyrighted materials in the Information Age. He adopts the widely known maxim of writer Stuart Brand that "[i]nformation wants to be free." 27 Barlow thus directly rejects the notion of information as a thing, especially on the Internet, where information is freed from its containers-the pages, books, tapes, film, and compact discs in which it formerly resided. When information ceases to be attached to any tangible medium, it becomes free to flow naturally as an "activity," a "life form," and a "relationship., ${ }^{28}$ Barlow suggests that current business models in the music industry fail to recognize the true nature of information on the Internet, and that copyright as it is currently known will not be able to adapt to

26. John Perry Barlow, Selling Wine Without Bottles: The Economy of Mind on the Global Net, at http://www.eff.org/pub/Publications/John_Perry_Barlow/HTML/idea_economy_article. html (last visited Sept. 5, 2001) (on file with the Duke Law Journal).

27. Id.

28. $I d$. 
the new "dematerialized information economy," ${ }^{29}$ in which there is no "final cut," and works remain "liquid" without being "fixed by a point of publication." $"$ 30

Professor Margaret Jane Radin also comments on the increasingly fluid nature of formerly "fixed" works. In her view, copyright protection "perpetuates the notion that property attaches to objects. ... 'Objects' in cyberspace, however-collections of bits that are apprehended as works - are ceasing to be fixed and tangible. They are becoming moving, dynamic, and malleable.... Works and the medium that embodies them are ceasing to be objects, and becoming processes." ${ }^{31}$ These commentaries suggest that information is liberated-made free-by its removal from any kind of tangible or physical medium. Barlow's conception of information naturally engulfs the realm of copyrighted music: "No longer will we mistake music for a noun, as its containers have tempted us to do for a century. We will realize once more that music is a verb, a relationship, a constantly evolving life form." ${ }^{32}$

Barlow's analysis of information and its dissemination on the Internet appears at first glance to be a fair one. If one understands "information" to mean ideas, concepts, and facts, and "free" to mean open and available to a wide audience, then it would seem obvious that "[i]nformation wants to be free." ${ }^{33}$ Once an idea is made accessible on the web, it is generally available to all who can find it, and it will more than likely be shared, lauded, criticized, manipulated, edited, revised, and ultimately adopted, incorporated, or rejected.

The expansive view of free information that Barlow suggests contains two fundamental errors. First, it seems to define "information" so broadly as to include all data that has been or can be digitized and made accessible on the Internet. Second, it understands "free" in a way that suggests that all information should not only be widely accessible, but accessible to everyone at no cost whatsoever.

By labeling all content on the Internet "information," Barlow would seem to allow the inhabitants of cyberspace to lay claim to all

29. John Perry Barlow, Napster.com and the Death of the Music Industry, at http://www. technocrat.net/958163435/index_html (last visited Sept. 5, 2001) (on file with the Duke Law Journal) (emphasis added).

30. Barlow, supra note 26.

31. Radin, supra note 11 , at 512.

32. Barlow, supra note 29.

33. Barlow, supra note 26. 
materials available online, regardless of whether they enjoyed a traditionally protected status in the real world. This type of logic essentially would require that any data made available on the Internet be relegated to the public domain. In Barlow's vision, copyright used to make at least some sense because musical "information" was stored in tangible media that had to be transferred or copied physically. ${ }^{34}$ But now that quality reproductions can be made at almost no cost and can be transferred without the exchange of any physical object, he seems to argue, copyright protection and intellectual property rights should fall away as an outdated and unwelcome reminder of a pre-digital, primitive understanding of property. ${ }^{35}$ Ideas, facts, concepts, and theories formerly could be distinguished as unprotectable "information," as opposed to the protected "property-things" of copyright. Under Barlow's system, the Internet removes that copyrighted content from the physical world (apparently ignoring the fact that the content simply has moved to computer hard drives from vinyl records or compact discs) and permits a blurring of the line between, on the one hand, the ideas and "information" that all rightfully share and, on the other hand, the creative expression that is deserving of respect, protection, and reward.

Ambiguity as to what counts as "information" is compounded by ambiguity as to what kind of "freedom" the information (apparently) demands and the Internet (apparently) promises. In an online article, Nicholas Petreley, a self-avowed "open source, free software, and free speech advocate," ${ }^{36}$ comments: "Take this mantra: 'Information wants to be free.' Horsehockey. Information doesn't want anything. People want information to be free. But face it: people want corned beef sandwiches on rye to be free, too. That doesn't mean we are entitled to them." ${ }^{37}$ There is a difference between stating that all information (whatever that might be) wants to be free and stating that all information should be available free of charge. What file-"sharing" and freesource advocates should not do "is license or buy existing information

34. See id. ("Copyright worked well because, Gutenberg notwithstanding, it was hard to make a book.").

35. See id. ("The riddle is this: if our property can be infinitely reproduced and instantaneously distributed all over the planet without cost, without our knowledge, without its even leaving our possession, how can we protect it?").

36. Nicholas Petreley, Napster and DeCSS: Is It About Free Speech or Free Stuff?, at http:// www.linuxworld.com/lw-2000-09/lw-09-penguin_1.html (last visited Nov. 2, 2000) (on file with the Duke Law Journal).

37. Id. 
that is not free and then cut it loose without permission. That's just plain wrong, and people who do it are demonstrating that what they are interested in is ... getting stuff without having to pay for it." ${ }^{38}$

These two fundamental misunderstandings-the expansive redefinitions of the words "information" and "free"-are causing a shift in moral expectations and claims of entitlement with respect to formerly protected materials. Perhaps a clearer translation of "information wants to be free" is "ideas should not be property." This formulation is perhaps less catchy, but it is conceptually neater and less subject to popular manipulation and misunderstanding. It also expresses nothing new, at least with respect to copyright protection. ${ }^{39}$ The more expansive and more popular articulation of this sentiment, however, results in the development of three new "truths," which, if left uncorrected, could easily become moral axioms of the digital world (if they have not been established as such already).

First, digitalization becomes equated with liberation. Anything that one might copy onto a hard drive or post to an Internet server becomes classified as "information," regardless of whether that label would have been appropriate when the material was in its real-world, or tangible, form. Second, availability is identified with entitlement, meaning that if it is technologically possible for one to access something in a digital form (or to make it available in such a form), one has a right to do so, since that is merely the natural realization of information's true state of being. Third, stealing becomes known as "sharing." If information is truly free, then it belongs to no one. No matter how one obtains information, it is rightfully in one's possession and, in turn, one is free to share it with anyone. Any restriction of that freedom to "share" could then be construed as a restriction of the individual's right to "interact" and "associate" freely with Internet peers.

Some of these new digital "axioms" already have been reflected in the comments that formerly were exchanged on Napster's message

38. Id.

39. See 17 U.S.C. $§ 102$ (b) (1994) ("In no case does copyright protection for an original work of authorship extend to any idea, procedure, process, system, method of operation, concept, principle, or discovery, regardless of the form in which it is described, explained, illustrated, or embodied in such work.”); Feist Publ'ns, Inc. v. Rural Tel. Serv. Co., 499 U.S. 340, 344-45 (1991) ("The most fundamental axiom of copyright law is that "no author may copyright his ideas or the facts he narrates."' (quoting Harper \& Row Publishers, Inc. v. Nation Enters., 471 U.S. 539, 556 (1985))); 1 DAVID NIMMER, NIMMER ON COPYRIGHT § 2.03[D] (2001) ("Copyright may be claimed only in the 'expression' of a work of authorship and not in its 'idea.” (citing Whelan Assocs., Inc. v. Jaslow Dental Lab., Inc., 797 F.2d 1222, 1234 (3d Cir. 1986))). 
boards:" "File sharing advocates and distributors are victims not thieves. ... Our choice to exchange whatever information or data ... with whom we chose [sic], for no commercial gain, and without restrictions [is the] embodiment of our right to freely associate and exchange information." ${ }^{, 1}$ That same Napster user also states that the rights to "freely communicate [and] exchange information are basic and fundamental," and that lawsuits such as those brought against Napster ${ }^{42}$ "are designed to effectively eliminate and restrict file sharing technology and are designed to restrict and limit the nature and scope of each individuals [sic] ability to interact with each other and to participate in an entire category of interaction, communication, and association." 43

Clearly, these concepts do not translate into the real world. It is highly unlikely that even the most adamant Napster user would suggest that one should be allowed to enter a record store, make copies of whatever one chooses, then make those copies available to anyone who might want them, not only without payment by the recipient, but also without financial reward to the artist. Even less plausible would be a defense of that kind of activity that involved a claim of freedom of association or interaction. Nor would one claim that just because one has purchased a compact disc, one should be entitled to take another copy from any record store one finds convenient. The physicality of the real world prevents this logic from taking hold. In the above scenarios, one would be stealing things, objects that are tangible, tactile, visible, and thus value-able. In cyberspace, however, the physicality of things falls away, and the notion of transferring to millions of anonymous listeners the music one either has purchased or has taken from somewhere else does not seem so wrong, since no thing is transferred. Often the only physical act required to effect the transfer is the simple click of a computer mouse. The digitized content that is transferred cannot easily be located in the physical world, so it is clas-

40. See Napster Speak Out Forum, Napster, at http://forum.napster.com/index.html (last visited Sept. 2, 2001) (on file with the Duke Law Journal) (displaying posted messages from Napster users). The Napster Forum has been suspended until Napster opens its new membership service. Id.

41. Posting of tericsen, Why Aren't Record Companies Being Sued?, to Napster Speak Out Forum, at http://forum.napster.com/ubb/Forum1/HTML/005528.html (posted Oct. 26, 2000) (on file with the Duke Law Journal).

42. A\&M Records, Inc. v. Napster, Inc., 239 F.3d 1004 (9th Cir. 2001).

43. Posting of tericsen, Response to Why Aren't Record Companies Being Sued?, to Napster Speak Out Forum, at http://forum.napster.com/ubb/Forum1/HTML/005528.html (posted Oct. 29, 2000) (on file with the Duke Law Journal). 
sified as "information," which demands to naturally and "freely" flow from one user to another. Thus, while music pirates exchanging compact discs hardly could claim freedom of association as a defense (without being greeted by hearty laughter from judges), it seems more feasible for Internet music pirates to do just that. For if music (once stripped of its physicality) is merely information, then what is being stifled by copyright holders is not illicit commerce or thievery, but discourse.

Although many Napster users adopt this type of libertarian, discursive philosophy, many others do not feel the need to embrace the notion that "information wants to be free." Some members of the filesharing community view free music downloads as an entitlement stemming from previous expenditures by music fans for "overpriced" recordings. "A lot of people are like, "Why should I feel guilty for downloading MP3s-I've seen all their concerts, I own all the CDs, I've bought T-shirts—-they've got my money already . ...", "Artists have been ripping us off for years! ... We only like one or two [of their songs, but if] we want to listen to the few, we have to buy them all.... Personally, I feel the artists owe the public alot [sic] of free downloads!"45

Others see the free exchange of copyrighted materials as an attack on a supposedly corrupt system which degrades music as an art form by considering its development and promotion as a business: "[Y]ou guys have RUINED music by turning it into a business and these 'artist' [sic] are not trying to make music they're trying to make money. So we are bringing back the soul [sic] reason as to why music is what it is. ${ }^{" 46}$ Music, once freed from the surface of a tangible medium, apparently regains a lost intrinsic and artistic value: "You lower your... prices and make music less hyped by superficial people like

44. Richard B. Simon, Metallica's Anti-Napster Crusade Inspires Backlash, at http://www. sonicnet.com/news/archive/story.jhtml?id=971500 (last visited Oct. 30, 2000) (on file with the Duke Law Journal) (quoting Mark Erickson, president and CEO of August Nelson, the online music company that runs PayLars.com, a "sarcastic site [that] allows fans to 'donate' $\$ 1$ for each officially released Metallica song, to 'make up for all the revenue the band thinks it's losing to online MP3 trading"').

45. Posting of heart2heart2000, NOW THE ARTISTS KNOW HOW WE FEEL!, to Napster Speak Out Forum, at http://forum.napster.com/ubb/Forum1/HTML/005613.html (posted Oct. 30, 2000) (on file with the Duke Law Journal).

46. Posting of JBunntLover, You Have Ruined Music, to Napster Speak Out Forum, at http://forum.napster.com/ubb/Forum1/HTML/004031.html (posted Sept. 28, 2000) (on file with the Duke Law Journal). 
Brinty [sic] Spears and Back Street boys [sic] and bring back what its [sic] all about or we are going to do it on our own!"47

The music industry should be alarmed by both the "noble" libertarian Napsterites and their more boisterous and revolutionary cousins (for reasons more significant than poor grammar and bad spelling). From the recording industry's perspective, Napster users, as well as the members of other file-sharing communities, regardless of their underlying ideology, have been seduced into believing that they are entitled to free music on the Internet. Contrary to the claim that Napster and its many clones reveal the true meaning and value of music by removing it from a commercialized context, the Recording Industry Association of America argues that "Napster is devaluing music itself, teaching an entire generation that music is free and has no value." ${ }^{\prime 4}$ The feeling of entitlement is something created and fostered by the "free"-for-all ethic of the Internet ${ }^{49}$ and must be addressed quickly before it becomes engrained as a popular truth. "Once consumers become accustomed to obtaining something for free, they resist paying for it. ... If the perception of music as a free good becomes pervasive, it may be difficult to reverse." ${ }^{50}$

The lawsuit against Napster ${ }^{51}$ is but one of several in the past few years aimed at controlling unauthorized "sharing" of copyrighted materials. ${ }^{52}$ Whether one views these suits as attempts by the industry to

47. Id. (emphasis added).

48. Napster Lawsuit $Q \& A$, Recording Industry Association of America, at http://www. riaa.org/Napster.cfm (last visited Oct. 30, 2000) (on file with the Duke Law Journal).

$[\mathrm{P}]$ erhaps the greatest danger posed by Napster ... is that consumers are beginning to consider free music to be an entitlement. This concept, of course, ignores and completely devalues both the work done by artists to create music and the funds invested by record companies to bring that music to the consumers.

Brief for A\&M Records, Inc., et al. at 14-15, A\&M Records, Inc. v. Napster, Inc., 239 F.3d 1004 (9th Cir. 2000) (No. 00-16401).

49. See supra notes $39-45$ and accompanying text.

50. Brief for A\&M Records, Inc., et al., supra note 48, at 14-15.

51. A\&M Records, Inc. v. Napster, Inc., 239 F.3d 1004 (9th Cir. 2001).

52. See Universal City Studios v. Reimerdes, 111 F. Supp. 2d 294, $345-47$ (S.D.N.Y. 2000) (permanently enjoining the defendants from disseminating DeCSS, a computer program that allows users to circumvent the anticopying technology contained in DVDs, thus making it possible to make digital copies of DVD content which then could be "shared" on the Internet); UMG Recordings, Inc. v. MP3.com, Inc., 92 F. Supp. 2d 349, 350-53 (S.D.N.Y. 2000) (holding MP3.com liable for copyright infringement for having copied more than 10,000 copyrighted CDs and making them available to the site's subscribers without permission); Twentieth Century Fox Film Corp. v. iCraveTV, No. 00-121, 2000 U.S. Dist. LEXIS 11670, at*3-*4 (W.D. Pa. Feb. 8, 2000) (enjoining iCraveTV.com from transmitting the plaintiffs' copyrighted television programming); see also Complaint at 2-4, Twentieth Century Fox Film Corp. v. Scour, Inc. 
eliminate peer-to-peer file-sharing technology altogether or merely to use its legal leverage to take control of that technology, the focus of the music industry's counterattack to the ethic surrounding the myth of free information is the technology itself. ${ }^{53}$ It is this technological structure and architecture that has fostered the free-for-all mentality of the Internet, and it is that same architecture that promises to reeducate the confused cyberlibertarian while at the same time quieting the revolt of copyright's virtual prisoners.

\section{II. "BuILDING" A SOLUTION: DisCIPLINARY ARCHITECTURE}

The philosophy of Michel Foucault provides a historical analysis of the development of the modern prison system from its origins in public spectacles of torture. The features Foucault attributes to modern disciplinary surveillance-automatic, supervisory, invisible-all can be analogized to the architectural controls which can be established on the Internet to control the flow of information as well as to observe those who access it.

\section{A. Foucault and the Historical Development of Disciplinary Surveillance}

In Discipline and Punish, ${ }^{54}$ Michel Foucault examines the structures of disciplinary power and their historical development as a reform of public torture. ${ }^{55}$ Through this reform, power becomes vested in a web of societal supervision and training rather than in the person of the sovereign. An inversion occurs in which the sovereign, who

(S.D.N.Y. 2000) (No. 00-5385), available at http://www.riaa.com/pdf/scourcomplaint.pdf (last visited Sept. 5, 2001) (on file with the Duke Law Journal) (alleging copyright infringement against Scour, a Napster-like website that allowed users to transfer not only music files, but also motion pictures). Scour.com soon decided to cease its operations in light of the pending litigation from the content industries. Clare Saliba, Scour.com to Quit File-Swapping, E-COMMERCE TIMES, at http://www.newsfactor.com/perl/printer/4842 (Nov. 15, 2000) (on file with the Duke Law Journal).

53. See Lessig, supra note 14, If 43 ("Rather than taking steps to protect their own content, many of these [music] companies have sought to make illegal the technologies that support this new mode of distribution.").

54. Michel Foucault, Discipline And Punish: The Birth of the Prison (Alan Sheridan trans., Vintage Books 2 d ed. 1995) (1977).

55. In the analysis that follows, I explore Foucault's historical analysis of visible punishment and disciplinary surveillance in an attempt to show one method for correcting the confusion that has resulted from the ethic of "free information." No attempt is made to incorporate into this Note the general tenets or undercurrents of Foucault's general philosophical project or to consider more than the most fundamental historical and analytical aspects of Discipline and Punish. Any indications or representations to the contrary are unintended. 
forged his superior individuality by tormenting the bodies of those who would dare challenge his status by asserting their own wills, fades away into obscurity, while the subject of punishment becomes individualized as the object of disciplinary surveillance, punishment, and study.

Early in Discipline and Punish, Foucault shows how the ritualistic display of torture is a response to what could be understood as a direct attack upon the power of the sovereign. "[B]y breaking the law, the offender has touched the very person of the prince; and it is the prince-or at least those to whom he has delegated his force-who seizes upon the body of the condemned man and displays it marked, beaten, [and] broken. ${ }^{, 56}$ By transgressing the law, the criminal in this primitive system dares to raise himself to the level of the prince, declaring himself an equal or superior in power by defying the will of the sovereign. The criminal, through his misdeeds, attempts to individualize himself, singling himself out from the herd within the sovereign's power. The sovereign, through a terrible display of physical strength and political authority, destroys this individuality, reestablishing himself as the solitary figure of independence, freedom, and power. It is the strong, swift hand of the prince that crushes dissent, reaffirming his position above the faceless, nameless crowd that swarms beneath his scepter.

The inversion of this open, visible display of the sovereign's power occurs with the abolition of public torture and the rise of supervisory structures and disciplinary punishment. In this inversion, the criminal - the object of discipline and training, as well as punishment - is the one who must at all times remain visible. In the former system, the object of the mechanisms of power could "remain in the shade ... . Disciplinary power, on the other hand, [was] exercised through its invisibility; at the same time it impose[d] on those whom it subject[ed] a principle of compulsory visibility." systems of punishment and correction, it is the criminal-the object of the mechanisms of power-who is individualized, isolated, recognized, and identified-made a visible subject. At the same time, the machinery of power remains anonymous and invisible, as the mechanism itself takes control. The principal example of this system of observational discipline in the real world is the Panopti-

56. FOUCAULT, supra note 54, at 49.

57. Id. at 187 . 
con ${ }^{58}$ which establishes an almost automatic exercise of anonymous power. The prisoners are individualized, each in a separate cell, always in plain view of the central tower, the occupants of which are hidden from the prisoners' view. ${ }^{59}$ This central tower enforces a silent, automatic rule of discipline, for the prisoners have no idea when they are being observed, or if they are being observed at all. ${ }^{60}$ Thus, the mere possibility of being observed - the potential for the discovery of misbehavior-imposes upon the prisoner a kind of self-discipline, where the authority - the faceless remnant of the sovereign-disappears further into the machinery of power. The theoretical result is a disciplinary and supervisory system in which power functions automatically, without maintenance and at a low cost. ${ }^{61}$ The structures of power Foucault describes-automatic, supervisory, invisible, decentralized-all seem analogous to the architectural codes of the Internet, which can silently and without outward signal control the behavior of the inhabitants of cyberspace. ${ }^{62}$

The Panopticon also individualizes the criminal by making him the subject of experimental observation and study: "The Panopticon is a privileged place for experiments on men, and for analysing with complete certainty the transformations that may be obtained from them." ${ }^{, 3}$ Similarly, the "trusted systems" that are (or soon will be) established on the Internet could track a wide variety of information about those who access or manipulate online works. ${ }^{64}$ The architectural code becomes both an exercise and a form of institutional power. "[W]e must ask of every exercise of power: Why? .. . 'Power,'

58. Foucault describes the Panopticon:

[A]t the periphery, an annular building; at the centre, a tower; this tower is pierced with wide windows that open onto the inner side of the ring; the peripheric building is divided into cells, each of which extends the whole width of the building .... [The cells] are like so many cages, so many small theatres, in which each actor is alone, perfectly individualized and constantly visible.... Each individual, in his place, is securely confined to a cell from which he is seen from the front by the supervisor; but the side walls prevent him from coming into contact with his companions. He is seen, but he does not see; he is the object of information, never a subject in communication.

Id. at 200 .

59. Id.

60. Id.

61. Id. at 201 .

62. I do not claim to be the first to recognize the potential application of Foucault's analysis of disciplinary power structures to Internet governance. See Boyle, supra note 8, at 184-88 (analogizing Foucault's unorthodox vision of power in terms of surveillance and discipline to the governing structure of the Internet).

63. FOUCAULT, supra note 54, at 204.

64. See infra notes 74-87 and accompanying text. 
in this account, is just another word for constraints that humans can do something about. ... [T] he architecture of cyberspace $i$ s power in this sense; how it is could be different." ${ }^{, 5}$

But how should the architecture be established, and who should make the important decisions involved in that determination? Who can claim the right to determine the boundaries of possibility on the Internet, and how will accountability be maintained? It has been argued that these questions should be answered through privatized efforts. ${ }^{66}$ In the case of online music swapping, that would mean that the music industry should seek to develop systems that would protect its interests.

From the content industries' perspective, the promise of a digital Panopticon should seem like a most wonderful solution to what at first glance looks like a daunting problem. Upon the anarchical system of the Internet, the industry quietly could impose a structure that would protect its rights, while providing detailed consumer information that would allow for targeted market research and advertising. ${ }^{67}$ Indeed, whoever controls the architectural code of the Internet will hold the virtual scepter of power in cyberspace.

\section{B. The Rise of the Internet Panopticon}

The computer architecture of the various spaces that comprise the Internet determines the possible spectrum of online conduct and behavior. ${ }^{68}$ The original architecture, as discussed in this

65. LESSIG, supra note 19, at 59 (second emphasis added).

66. See Boyle, supra note 8, at 196-202 (proposing that the government look to "privatized enforcement and surveillance, cost spreading, and the use of 'material coercions rather than the physical existence of a sovereign'" in governing the Internet).

67. In an online article posted on the RIAA website, Thomas Dolby Robertson comments on possible marketing possibilities once the music industry has fully incorporated digitized distribution:

What the Web offers labels is a unique opportunity to understand, for the first time, what really makes the public tick. Who they are, why they buy, what else they do when we're not buying CDs. There's never been a marketing platform like it. Armed with this information, a label ought to be able to precisely target the correct demographic for its artist, and cut out the wastage in its marketing budget. No more full page ads in Rolling Stone, where $90 \%$ of the eyeballs will belong to the wrong type of crowd. No more expensive radio and TV ad campaigns, or mindless flyposting of walls in major cities.

Thomas Dolby Robertson, The Upside of Music on the Web, Part 2: How Technology and Music Impact Each Other, Recording Industry Association of America, at http://www.riaa.org/Guest_ Column0301.cfm (Sept. 2000) (on file with the Duke Law Journal).

68. See Lessig, supra note 14, II 12 ("[T] he architecture or design of cyberspace regulates behavior in cyberspace."). 
Note, ${ }^{69}$ promised a type of freedom and interaction that seemed impossible in the real world. What accompanied that promise of freedom was a loss of control and regimentation. "The Internet changed the balance of protection afforded by law, by enabling behaviors that weaken the protections of a legal regime." ${ }^{, 70}$ While this weakening of governmental influence was apparent on many fronts, ${ }^{71}$ Professor Lessig suggests that the greatest threat lay in the area of copyright protection. $^{72}$ The original architecture of the Internet permitted perfect digital copying at negligible (if any) cost and permitted equally costless distribution. ${ }^{73}$ Lessig argues that while the early architecture of the Internet posed a threat to copyright protection, developments in code have the potential to create an era of almost perfect copyright protection on the Internet-a level of protection that could surpass anything possible in the real world. ${ }^{74}$

[C]yberspace does not guarantee its own freedom but instead carries an extraordinary potential for control. . . . Too many believe liberty will take care of itself. Too many miss how different architectures embed different values, and that only by selecting these different architectures-these different codes-can we establish and promote our values. ... Architecture is a kind of law: it determines what people can and cannot do. ${ }^{75}$

The idea of using a coded system to protect legal copyrights by making it technically difficult to infringe upon them is not unique to the Internet. A less perfect system of architectural copyright protection was established in response to what was considered by many to be a similar, real-world threat to copyright-Digital Audio Tape (DAT). The eventual response to the threat of a machine that could

69. See supra Part I.A.

70. Lessig, supra note 14, II 28.

71. See id. III 27-28 (commenting on the consequences of the Internet for "control of speech, the protection of privacy, the defense of copyright, the protection against fraud, or the protection of children").

72. Id. If 33 ("Many have argued that no threat to legal protection on the Internet is greater than the threat the Internet presents for copyright. For the same reason that cyberspace strengthens free speech, it simultaneously renders the protection of copyrighted material particularly vulnerable.").

73. Id. II 34.

74. Id. II 35 ("Technologies are being developed that can radically increase the protection and control that copyright holders have over their copyrighted material. These technologies will ... make it possible for copyright holders to exercise more control over the use of copyrighted material than they could in real space.").

75. LESSIG, supra note 19 , at 58-59. 
produce perfect, digital copies of compact discs was a change in the architecture of that machine itself. ${ }^{76}$ The technology was changed to degrade deliberately the quality of each successive recording, thus wiring into the machine a protection against infinite, perfect copying. ${ }^{77}$ The previous technology's physical limitations were programmed into the new technology to maintain the previous level of protection. On the Internet, however, developments in code would permit copyright holders not only to maintain the level of protection against impermissible copying and distribution that exists in the real world, but also actually to surpass it. ${ }^{78}$

Lessig refers to these developments in code as "trusted systems." ${ }^{79}$ With these systems, copyright holders could use software to perfect control over their works, without resort to legal action, governmental intervention, or social normative reform. "Trusted systems" could control when and how a copyrighted work is accessed, manipulated, edited, and transferred. "The technology, in other words, would give the copyright holder a kind of power over the user of copyrighted material that the copyright holder has never before had."

Copyright orders others to respect the rights of the copyright holder before using his property. Trusted systems give access only if rights are respected in the first place. The controls needed to regulate this access are built into the systems, and no users (except hackers) have a choice about whether to obey these controls. The code displaces law by codifying the rules, making them more efficient than they were just as rules. ${ }^{82}$

Thus, the architecture of the Internet, which originally had suggested that copyright protection would be profoundly difficult or impossible in the digital realm, could be modified to create a space of almost perfect copyright protection, where users would have even less power to access, manipulate, and duplicate works than they have in the real

76. Id. at 127-28; Boyle, supra note 8, at 204.

77. LESSIG, supra note 19, at 127-28; Boyle, supra note 8, at 204.

78. See infra notes 79-87 and accompanying text.

79. LESSIG, supra note 19, at 127-30; Lessig, supra note 14, If 36.

80. Lessig, supra note 14, II 36 (citing Mark Stefik, Shifting the Possible: How Trusted Systems and Digital Property Rights Challenge Us to Rethink Digital Publishing, 12 BERKELEY TECH. L.J. 137 (1997)).

81. Id.

82. LESSIG, supra note 19 , at 130. 
world. Technologies like Secure Digital Music Initiative (SDMI) ${ }^{83}$ and digital watermarks ${ }^{84}$ offer copyright holders the potential to restrict copying of protected materials and to track the uses of those copies that are permitted. ${ }^{85}$ These new technologies also might be used to track information about how their protected works are used and who is using them. "Documents will keep track of how many times they are read and may complain if they are read too much or by the wrong person. ... [These will be] texts that 'rat' on you." ${ }^{\text {"T6 }}$ This information would be part of a system in which individual (and perhaps individualized) fees could be charged for every infinitesimal use-even those that would have been considered free or "fair" in the real world. ${ }^{87}$

Such ultraprotective architectural codes would offer protection for copyrights unparalleled by any protection available in the real world. Digital technology, which once promised to be a scalpel, severing works from the protection of copyright, very soon could coil its sharp edges into a barbed wire, guarding against anyone who wishes to gain access. The digital fences that could be, and already have been, erected could create a virtual Panopticon that would prevent unauthorized use of protected works and permit the works themselves to keep vigilant watch over those with access to them.

83. See Lessig, supra note 14, II 37 (describing the proliferation of "tagging" mechanisms for copyrighted materials); SDMI, SDMI Frequently Asked Questions, Secure Digital Music Initiative, at http://www.sdmi.org/faq.html (last visited Oct. 27, 2000) (on file with the Duke Law Journal):

The only content SDMI-compliant devices will not play is illegally copied SDMI music .... The specification allows consumers to copy (rip) their CDs onto their computers for personal use (on their PC, on their portable devices, on their portable media, etc.). In fact, the specification enables consumers to do so as many times as they wish-as long as they have the original disk.

(emphasis added).

84. See Doug Isenberg, Digital Watermarks: New Tools for Copyright Owners and Webmasters, WebReference.com, at http://www.webreference.com/content/watermarks (last visited July 30, 2001) (on file with the Duke Law Journal):

Digital Watermarking, sometimes called "fingerprinting," allows copyright owners to incorporate into their work identifying information invisible to the human eye. When combined with new tracking services offered by some of the same companies that provide the watermarking technology, copyright owners can, in theory, find all illegal copies of their photos and music on the Internet and take appropriate legal action.

85. See supra notes $80,83-84$, and accompanying text.

86. Boyle, supra note 8, at 201 (citing Pamela Samuelson, Will the Copyright Office Be Obsolete in the Twenty-First Century?, 13 CARDOZO ARTS \& ENT. L.J. 55, 58 n.18 (1994)).

87. LESSIG, supra note 19, at 135-39. 


\section{A DisPlay OF SOVEREIGNTY: THE "TORTURE" OF NAPSTER AS PUBLIC SPECTACLE}

To institute a system of digital surveillance and automatic power on the Internet, the content industries first must make a public display of that power. Although certainly not the only example, ${ }^{88}$ the lawsuit against Napster has provided the music recording industry the opportunity to make a very public example of what is (or at least was at the time of the suit's initiation) the largest of the Internet's filesharing communities. ${ }^{89}$ To efficiently and legitimately establish a regime of copyright protection on the Internet, the recording industry effectively must "torture" Napster in full public view, reasserting its property rights in cyberspace against the rebellious challenge made in the name of free discourse and "sharing."

\section{A. The Internet as Prison Riot}

Foucault's analysis of disciplinary power shows that the Panoptical system not only applies to prisons, but also is found in many of the structures that define who people are and what they become: "The practice of placing individuals under 'observation' is a natural extension of a justice imbued with disciplinary methods and examination procedures. . . . Is it surprising that prisons resemble factories, schools, barracks, hospitals, which all resemble prisons?" If the structures of power have become so pervasive in society that one cannot escape them-in fact, if one is defined by them-then would not the Internet be a revolt from that disciplinary system? Is the Internet not then essentially a prison revolt?

The Internet originally was designed to avoid the restrictions, observations, and controls that burdened the real world. ${ }^{91}$ Recall the manifesto Professor Lessig cites: "We reject: kings, presidents and

88. See supra note 52 and accompanying text.

89. See Matt Richtel, With Napster Down, Its Audience Fans Out, N.Y. TIMES, July 20, 2001, at A1 (noting that Napster once claimed over seventy million users, but that the number of downloads had dropped by as much as ninety-five percent since the service was required by court order to begin blocking the transfer of copyrighted materials).

90. Foucault, supra note 54, at 227-28; see also Mathieu Deflem, Power/Knowledge, Society, and Truth: Notes on the Work of Michel Foucault, at http://www.sla.purdue.edu/people/soc/ mdeflem/zfouc.html (Apr. 1999) (on file with the Duke Law Journal):

The "carceral system" becomes complete when cloister, prison, school and regiment come together. Al[1] these systems are characterized by training, observation, knowledge and perpetual assessment of the soul. ... [T] he society is the prison.

91. See supra Part I.A. 
voting. ${ }^{, 92}$ The Internet can be viewed as a rebellion against the disciplinary surveillance of modern society. The Internet has created a space in which one can shed the name, identity, and social status handed down and created by the structures of disciplinary power. One can abandon the traditional norms and rules of society that are taught in schools and enforced in prisons. And most importantly, one can do it anonymously and invisibly. The Internet seems to be the one place the prying eye of discipline cannot see, or, if it can see, the one place it cannot see very well.

If the Internet is a rebellion against the disciplinary structures of the real world, then the rebellion must be crushed to establish "real" order and stability. In this respect, the last vestiges of the invisible sovereign must rear up, reveal themselves once again momentarily, and, in a transitory display of force, establish in this new world the order of the old system that the Internet subverted. It is the rarest of prison riots that can be quashed by invisible surveillance. Once the system of observation has broken down, it takes a show of force to restore and stabilize things once again. When the prisoners smash all the video cameras and take control of the central observation tower, it may take just the sound of one gunshot and the sight of one dead inmate to restore the sanity of ordered control. Perhaps it will take the execution of Napster-arguably the ringleader in the revolt-to make Internet users realize that in fleeing reality by entering cyberspace, they have not escaped society's prison, but have, ironically, merely encapsulated themselves in a different cell.

\section{B. The Benefits of Public "Torture"}

The most significant and immediate benefits of shutting down Napster and its progeny will be to the content industries, which will have sealed off an avenue of copyright infringement and media piracy. The exercise of sovereign power extends legitimacy to whatever surveillance system is established. Also, the visibility of that power might help disrupt the popularized notion of "free information."

1. Legitimacy. By "torturing" Napster in public view, the recording industry makes a claim of right or authority to establish the supervisory system it likely will establish. Instead of merely estab-

92. Lessig, supra note 19, at 4 (quoting Paulina Borsook, How Anarchy Works, WIRED, Oct. 1995, at 110 (emphasis added)). 
lishing a system of digital fences, watermarks, or other new copyrightprotective technologies in secret, the music industry also needs to make an open, unabashed, and honest claim about its rights and power in cyberspace. If Lessig is right that "the space is sovereign," 93 then a show of individual power must be made to change the space. Without this open show of power as a claim of legitimate authority, the imposition of a new architecture-especially one that significantly restricts the formerly unchecked flow of information-might seem arbitrary and unjustifiable. By vigorously pursuing its lawsuits against Napster,${ }^{94}$ the music industry can obtain what is in effect the grant of a legal right to exercise its power in cyberspace. By openly claiming this right (and displaying it by shutting down Napster's infringing activities), the legitimacy of the forthcoming architectural imposition is preserved against claims that the music industry is acting without moral or legal authority.

2. Visibility. The spectacle of public violence confronts those who witness it with a show of power, might, and authority. By establishing its system, Napster openly and directly has challenged the legitimacy of copyright protection on the Internet (if not everywhere). ${ }^{95}$ In this sense, it has "touched the very person of the prince," ${ }^{, 96}$ flaunting any claim of authority that the music industry might have in cyberspace. By obtaining a very public condemnation of Napster's ac-

93. LESSIG, supra note 19, at 198.

94. The recording industry generally has been aggressive in its legal pursuit of Napster, especially during the summer of 2001, when a district court in California required Napster (which already had ceased its file-swapping services while it upgraded its servers and other technology) to remain offline until such time as it could implement software which would block 100 percent of transfers of copyrighted materials. See Reporter's Transcript of Proceedings In Re Napster Copyright Litigation, No. MDL-00-1369 MHP (N.D. Cal. July 11, 2001), at 32, available at http:// news.findlaw.com/cnn/docs/napster/transcript071101.pdf (last visited Oct. 5, 2001) (on file with the Duke Law Journal) ("It's not good enough until every effort has been made to, in fact, get zero tolerance . . . . There should be no copyright infringement, period."). At the time of the order, Napster's software was capable of blocking approximately $99.4 \%$ of infringing transfers. $I d$. Judge Patel's order, unfortunately, was reversed by the Ninth Circuit Court of Appeals soon thereafter. A\&M Records, Inc. v. Napster, Inc., No. 01-16308 (9th Cir., July 18, 2001), available at http://news.findlaw.com/cnn/docs/napster/9thcir71801ord.pdf (last visited Oct. 15, 2001) (on file with the Duke Law Journal). The Recording Industry Association of America noted in its response to the reversal that "the court only temporarily lifted Patel's order and will hear arguments on the case later this year." Associated Press, Napster Allowed to Go Back Online, Chattanooga Times, July 19, 2001, at C2.

95. See Brief for A\&M Records, Inc. et al., supra note 48, at 2 (quoting an internal Napster document that admits its users will be "exchanging pirated music").

96. FOUCAULT, supra note 54, at 49 . 
tivities, and by effectively destroying Napster (through a permanent injunction and a significant damage award), the music industry can stake its claim to power and right on the Internet. At the same time, this display of destructive power might awaken or startle those who witness it (especially Napster users) from the illusion of free information. By executing Robin Hood publicly, the sovereign might remind a few of the merry thieves that stealing is wrong and will be punished, no matter how praiseworthy the perpetrator or villainous the victim.

But the benefits of the public torture of Napster will not be limited to the content industries. Despite the "harm" suffered by advocates of free information, there are some latent advantages to Internet users from this type of public display of authority.

First, the visibility of a public spectacle like the Napster lawsuit ensures that users know who established the disciplinary system under which they live. The music industry must identify itself as a major impetus for the erection of digital fences and similar impediments to the flow of information. The industry cannot hide behind claims of market forces or other invisible hands. Those who will have their wrists bound with digital cuffs, and who will be tagged and observed as they navigate cyberspace, will thus be aware of these restrictions. ${ }^{97}$ When the restrictions are hidden in the architecture of the space itself, it is paramount that people be made aware of their existence and of their contingency, since otherwise they might consider those structural restrictions to be "just the way things are.",

Second, this type of a showing of sovereign power establishes a focus or center from which the disciplinary system can be said to originate, thus resulting in some accountability for those who establish it. The visibility of the destructive force of the music industry as effected upon Napster would identify the music industry as the author of the disciplinary system that likely would replace current filesharing technologies. In this respect, "the way things are" would be revealed not as the result of anonymous evolution or the unfolding of inevitable technological fate, but rather as the direct result of an imposition by an authority. Thus, "the way things are" becomes "the

97. Visibility in this sense also is valuable to the sovereign if the display of power is to have any deterrent or preventative effect. "The person constrained must know of the constraint. A law that secretly punishes people for offenses they do not know exist would not be effective in regulating the behavior it punishes." LESSIG, supra note 19, at 238.

98. Boyle, supra note 8, at 205 ("The technology appears to be 'just the way things are'; its origins are concealed, whether those origins lie in state-sponsored scheme or market-structured order, and its effects are obscured because it is hard to image the alternative."). 
way things have been made to be." If the controls and restrictions become oppressive, unreasonable, impracticable, or unconstitutional, Internet users will know at whom to direct their accusations.

\section{Why Settlement Is No Option}

Why has the music industry apparently chosen to eliminate Napster completely? Why did it not use the leverage of the lawsuit and impending legal judgment against Napster to force a settlement that would have allowed the content industries to acquire file-sharing technologies and utilize them for their own gain? ${ }^{99}$

Settlement would have tended to discredit the legitimacy of the music industry's claim of sovereign right. This air of illegitimacy could have taken two forms, both of which relate to the adequacy of the industry's claims against Napster. Settlement could have weakened the apparent strength of the music industry's claims, giving the appearance that Napster's defenses carried such weight and strength that the industry had to give in, rather than risk the embarrassment of a legal defeat. Also, failure to see the lawsuit through to a final judgment could have left open the important question of whether Napster's activity was definitively illegal or improper. The lack of a final resolution would have allowed those who believe file sharing to be a protected right akin to expression or association to persist in that belief. And those who view free online music to be an entitlement premised on the music industry's abuse of its copyrights would have been able to claim that Napster's demise was not the result of legal or moral culpability, but was merely the result of the music industry's formidable leverage and financial strength. Either way, any subsequent limitations on music downloads imposed by a deal between Napster and the music companies would have lacked the legitimacy the limitations will have if Napster is defeated and disabled.

Settlement not only would have legitimized Napster's defenses, it also would have made Napster appear in the eyes of some of its more idealistic supporters to be a traitor to its revolutionary founding principles. While settling with Napster would have ingrained even more deeply the idea that file sharing is a legitimate activity being unfairly suppressed by an evil and greedy music industry, it also would have undermined file sharers' loyalty to the Napster service. Thus, the set-

99. For a discussion of one of the companies which already has settled its lawsuit with Napster, see infra notes 100-09 and accompanying text. 
tlement agreement would have been self-defeating from a business perspective as well. Robin Hood would lose the support of his followers if they learned he had replaced his rebellious ideals and activities with the title of "tax collector" and a paycheck from the king.

One plaintiff in the Napster lawsuit, Bertelsmann, reached a settlement agreement with the service..$^{100}$ The response of Napster users was hardly optimistic or relieved. "Initially, Napster.com depicted itself as a challenger to the present system of intellectual copyright," one user wrote. "It was to be a community ... of free file sharing; akin to having several thousand people in your basement sharing and appreciating a diverse range of music." ${ }^{, 102}$ A settlement or licensing agreement with record companies merely would make Napster an extension of the corporate machinery that free information advocates rebel against. "It appears Napster.com was never about a 'free' community committed to sharing but about putting Napster into 'play' with the major record labels. . . . How else does Napster explain the secretive and relatively unexpected announcement of a 'partnership' with BMG? ... [T] he revolution was always for sale."103

Napster users easily could have become disenchanted with a service they viewed as having "sold them out." If Napster users envisioned themselves as fighting the status quo together with the creators of the Napster service, they would have felt betrayed if the service secretly stopped the rebellion by hopping into bed with the enemy. ${ }^{104}$ One user complained that Napster, by "having taken money from a large record label has sold us out.... Your storage space, internet connection, collection of MP3s has been handed over to a record label. They now talk of using our resources to sell MP3s to me and you. ... WE HAVE BEEN SOLD OUT." ${ }^{105}$

\footnotetext{
100. E.g., Brad Stone, The Odd Couple, NewsweEK, Nov. 13, 2000, at 56-57.

101. Posting of HistoryNut, Is the Revolution Dead?, to Napster Speak Out Forum, at http:// forum.napster.com/ubb/Forum1/HTML/007179.html (posted Nov. 14, 2000) (on file with the Duke Law Journal).

102. Id.

103. Id.

104. The close-knit relationship between Napster and Bertelsmann has become even more intimate. On July 24, 2001, Napster announced that Konrad Hilbers, former executive vice president and chief administrative officer for Bertelsmann would become chief executive officer of Napster, Inc. Napster Announces Konrad Hilbers as CEO, Napster, at http://www.napster. com/pressroom/pr/010724.html (July 24, 2001) (on file with the Duke Law Journal).

105. Posting of Internet_Warrior, Napster Has Sold Us Out, to Napster Speak Out Forum, at http://forum.napster.com/ubb/Forum1/HTML/007126.html (Nov. 13, 2000) (on file with the Duke Law Journal).
} 
Settlement also would not have prevented the departure of users from Napster to another, decentralized file-sharing service like Gnutella. ${ }^{106}$ Users who refuse to pay even a nominal fee are being lured by the cost-free nature of substitute services that offer the same file-sharing capabilities as Napster. Those who feel betrayed by Napster's "selling out" will prefer the even more decentralized (and thus more rebellious) systems. Within days of the settlement announcement with Bertelsmann, some Napster users began jumping ship.

Fans are turning to alternatives. "We'd been getting a few hundred new members each day, but that increased to several thousand" Wednesday [the day after the Bertelsmann agreement was announced], says Gavin Hall, 20, co-founder of Napster clone Songspy.com. Online for a month, Songspy, with 30,000 members, vows to stick with a policy of free music. "We don't want to betray our users like Napster did," Hall says. "Charging dues is not in the spirit of sharing." 107

This exodus has continued, especially during Napster's recent selfimposed, and temporarily court-mandated, shut-down. ${ }^{108}$ "Other programs used to exchange music .... have emerged ... [not only] as users have become accustomed to obtaining music online but [also] as a vacuum was created by the demise of Napster . . . ."109

It is clear that merely eliminating Napster will not end the misconception of "free information" and the culture of entitlement that accompanies it completely. ${ }^{110}$ Some ardent rebels will seek new sources of free music, moving away from the servers of Napster to more elusive, decentralized systems like Gnutella. ${ }^{111}$ These services might pose an even greater threat to the content industries than did Napster, since the newest generation of file-swapping technologies is

\footnotetext{
106. Professor Lessig comments:

Gnutella is a simple substitute for Napster. It facilitates a better peer-to-peer searching capability, and is operated in a far more decentralized manner... Thus, the existence of Gnutella means that any regulation of Napster is likely ultimately to be ineffective. There is no barrier to limit consumers switching from Napster to Gnutella.

Lessig, supra note 14, IIII 66-67.

107. Jefferson Graham, Napster's Bertelsmann Alliance Isn't Music to All Ears, USA TODAY, Nov. 2, 2000, at 1A.

108. Richtel, supra note 89 , at A1.

109. Id.

110. See, e.g., id. (explaining that many Napster users have switched to other, more decentralized music-sharing programs in the absence of Napster).

111. See id. (noting that the newer decentralized systems are now easier to use and harder to police).
} 
easier to use than ever. ${ }^{112}$ These new technologies are "becoming increasingly more difficult to police, possibly forcing record companies to sue individual users, a daunting, if not impossible task." ${ }^{, 13}$ It is possible that the display of power necessarily might extend beyond Napster and other Internet services to the users of those services themselves, perhaps by seeking criminal prosecution of the most egregious and flamboyant (and perhaps the proudest) advocates of file sharing. ${ }^{114}$ A prime target for such prosecution would be someone like the "law office manager in Tampa, Fla., and former Napster user who has moved to MusicCity.com," who has said that "he had downloaded more than 120 full albums in the last year from the Internet, first from Napster, then from MusicCity, and he said he had not bought a single album during that time."115

The music industry cannot hope to counter the true threat to copyright on the Internet-the "spirit" of "sharing information"without a visible and definite display of power, first against services like Napster, and perhaps later against the individuals who use them. Without some way to reform the ethic of "free information" and the sense of entitlement that accompanies it, technological advances meant to protect copyright in cyberspace will lack legitimacy and will be resisted perpetually. The music industry need not achieve support for its position. Internet users need not become ardent supporters of copyright law. But the "spirit of sharing" must be broken if copyright is to survive. The wild horse must be broken before it can be trusted alone in its stable.

\section{CONCLUSION}

The metaphysicality of the Internet allows people to shed the moral limitations and social stigmas that inhibit transgression of social norms in the real world. In most instances, this merely permits people

\footnotetext{
112. Id.

113. Id.

114. Copyright law provides for criminal prosecution of willful infringement. See 17 U.S.C. § 506(a) (1994):

Any person who infringes a copyright willfully either-

(1) for purposes of commercial advantage or private financial gain, or

(2) by the reproduction or distribution, including by electronic means, during any 180-day period, of 1 or more copies or phonorecords of 1 or more copyrighted works, which have a total retail value of more than $\$ 1,000$,

shall be punished as provided under section 2319 of title 18, United States Code.

115. Richtel, supra note 89, at A1 (emphasis added).
} 
to conduct themselves in the same way they would in the real world could they avoid detection. However, the formless freedom of the Internet, as well as its lack of physicality, results in an additional moral shift with respect to the infringement of copyrighted materials. The widespread, unauthorized, and free distribution of digital media on the Internet allows people to take advantage of their virtual invisibility by appropriating music with great ease, minimal (if any) social stigma, and very little chance of detection. The structure of the Internet also confuses them into thinking that they are entitled to the things they steal. Free-flowing, non-restrictive "sharing" technologies like Napster have been developed, effectively cutting the lock to the candy store door. Unfortunately, the children who have been stealing candy feel they have a right to complain when the store owner contemplates buying a new security system.

This situation represents a revolutionary departure from the moral and legal restrictions of the real world. The proper response (from the perspective of the music and other content industries) is a show of sovereign power, which quiets what is in effect a revolt from the "prison" of ordered, real-world society. By vigorously pursuing its suits against Napster and other similar file-sharing services, the music industry can make that show of power.

Through this public display, the music industries can momentarily centralize and visualize the power structures that will guide the future of the Internet. This moment will be followed by a quiet retreat into silent observation, where the centralized power exerted on the Internet by the content industries can diffuse into an architectural power incorporated into the very architecture of the Internet, which will exercise control from within. The moment of visualization is necessary to make the subsequent architectural power structures more legitimate and effective. By urging the music industry to seek complete victory over Napster, I do not mean to endorse completely the industry's claims or the likely results that would follow from their legal success against Napster and other file-sharing services. I intend merely to suggest that making the display of power over Napster public and complete will be the most legitimate, efficient, and successful means by which the industry can establish a true system of copyright enforcement in cyberspace.

Those who support Napster and the relaxation of copyright laws to permit music "sharing" on the Internet should not necessarily decry my call for a display of authority. If the music industry takes a public and visible approach to asserting its claimed property rights, it 
necessarily will make itself accountable for its actions. The music industry also will expose itself to criticism for the approach it takes and for the institutional and architectural changes it imposes on the Internet. The music industry will not be able to shirk responsibility for the imposition of architectural controls that most certainly will come to encapsulate digitized copyrighted materials. "The way things are" will not be considered the result of happenstance or an accident of history, but rather will be the direct consequence of an affirmative, public action taken by an identifiable sovereign. The king, before dissolving into the secret mechanisms of power, must stand triumphantly over the broken body of the defeated rebel. But in doing so, he lets potential assassins know precisely where to take aim. 